\title{
INTERAKSI MODEL PEMBELAJARAN DAN HASIL BELAJAR IPA TERHADAP KEMAMPUAN MEMECAHKAN MASALAH LINGKUNGAN HIDUP
}

Studi Eksperimen Terhadap Siswa Sekolah Dasar Laboratorium UPI

Kampus Cibiru Bandung

\section{Dede Margo Irianto, Lektor Kepala Pada UPI Kampus Cibiru}

\begin{abstract}
The aim of the research was to identify the influence of learning models and science learning outcomes on the ability to solve problem in environmental education learning at the elementary school.

This research was conducted at SD Laboratorium Upi Kampus Cibiru, Bandung. Experimental method with factorial plan $2 x 2$ was the method that was employed in this study. The sampling objects were 40-fourth grade students. Twenty of them achieved high learning outcomes in environmental study meanwhile the remains were having low learning outcomes. Two ways variant analysis (ANAVA) was used in hypothesis test and then continued by Turkey test.

The research conclusions were: (4) There were connection between learning models and science learning outcomes on the ability to solve environmental problem in the learning environmental education.
\end{abstract}

Keywords : constructivist model of learning, interactive model of learning, environmental problem, science learning outcomes.

\section{Pendahuluan}

Beberapa fenomena berkaitan dengan kualitas lingkungan yang nampak di sekitar, menyadarkan orang bahwa penurunan kualitas lingkungan memang sedang terjadi dengan kecepatan yang sangat mengkhawatirkan. Ada beberapa indikator yang menunjukkan terjadinya penurunan kualitas lingkungan. Indikator-indikator tersebut adalah pencemaran dan limbah, berkurangnya sumber energi di alam yang dapat dimanfaatkan, terjadinya degradasi lahan, berkurangnya keanekaragaman hayati, dan makin berkurangnya sumber daya air. Indikator-indikator tersebut memiliki pengaruh yang besar dalam menentukan kualitas suatu lingkungan.

Di daerah perkotaan, terutama di tempat peneliti bertempat tinggal, yaitu di
Kabupaten Bandung, semua indikator yang menunjukkan menurunnya kualitas lingkungan itu nampak sangat jelas. Kondisi serupa terlihat di sekolah-sekolah, terutama di sekolah dasar (SD) yang peneliti amati.

Merosotnya kualitas lingkungan yang dapat dilihat dan dirasakan sekarang ini, menuntut adanya tindakan yang harus segera dilaksanakan. Tindakan ini diperlukan agar dapat mencegah terjadinya kemerosotan kualitas lingkungan yang terus menerus, yang pada akhirnya dapat menjadi bencana yang menyengsarakan semua. Salah satu aksi lingkungan yang dilaksanakan dalam bentuk class action adalah berupa program pendidikan lingkungan. Program ini dirasakan dan dinyatakan sebagi program pendidikan yang berperan dalam mengembangkan literasi lingkungan pada diri individu. 
Kualitas lingkungan hidup yang semakin menurun berkaitan erat dengan pemahaman konsep lingkungan dan perilaku manusia terhadap lingkungan hidupnya. Penanaman kesadaran manusia untuk berperilaku hidup bersih dan sehat merupakan hal yang tidak mudah dilakukan karena usaha ini memerlukan waktu yang relatif lama melalui kegiatan pembelajaran, kesadaran serta pembiasaan pada diri manusia sendiri. Kegiatan pembelajaran yang berisi pengetahuan tentang lingkungan hidup di sekolah masuk ke dalam kurikulum muatan lokal yang merujuk pada peraturan Gubemur Jawa Barat no 25 tahun 2007. Dalam UU No. 23 Tahun 1997 Tentang Pengelolaan Lingkungan Hidup sesungguhnya tidak bermaksud untuk mengatur lingkungannya, tetapi lebih ditujukan untuk mengatur sikap dan perilaku manusia terhadap lingkungan (Nurhayati, 2012:2).

Dalam pelaksanaan pembelajaran PLH di Lembaga-Lembaga Pendidikan resmi (SD s/d Perguruan Tinggi). Efektivitas dan kebermaknaan pembelajaran PLH yang mampu membuat pihak yang terlibat di dalamnya, terutama peserta didik memiliki kemampuan bertindak berdasarkan kecerdasan untuk memecahkan permasalahan lingkungan masih terasa kurang. Cronbach $(1977 ; 92)$ berpendapat bahwa pembelajaran merupakan suatu perubahan tingkah laku sebagai hasil pengalaman. Ausabel $(1963 ; 34)$ mengemukakan teori tentang pembelajaran bermakna, yaitu supaya suatu proses pembelajaran menjadi bermakna maka konsep baru atau informasi baru harus dikaitkan dengan konsep-konsep yang telah ada dalam struktur kognitif siswa.

Dalam pelaksanaannya pem-belajaran PLH berlangsung kurang bermakna dan kurang efektif ini terjadi di antaranya adalah karena para guru PLH belum menerapkan pendekatan dan metode pembelajaran yang bervariasi dan cocok. Dari hasil pengamatan peneliti terhadap pelaksanaan pembelajaran PLH terutama di SD., nampak bahwa kegiatan pembelajaran lebih bersifat teoritis dan tidak terlalu menuntut siswa untuk secara praktis dan aplikatif menerapkan apa yang diperoleh dalam pembelajaran untuk memecahkan permasalahan lingkungan yang dihadapinya dalam kehidupan sehari-hari.

Lieberman dan Hoody (1998;87) menyatakan bahwa pendidikan lingkungan telah menjadi pelopor dalam mendorong pendidikan interdisipliner, pemikiran kritis dan pemecahan masalah. Salah satu bentuk pendekatan dalam pembelajaran pendidikan lingkungan adalah pendekatan secara menyeluruh yang mencakup : 1) menawarkan cara yang efektif untuk mengintegrasikan kurikulum, 2) mengembangkan keterampilan berpikir kreatif dan kritis, 3) mengembangkan keterampilan riset untuk membantu memecahkan masalah bagi siswa, 4) menyelidiki sikap dan nilai-nilai antar budaya, 5) melibatkan berbagai kecerdasan, 6) melibatkan siswa dalam masyarakat, 7) menggunakan strategi pembelajaran yang berpusat kepada siswa sehingga siswa terlibat secara aktif dalam proses belajar.

Dalam melaksanakan PLH seperti diuraikan di atas, diperlukan model pembelajaran yang tepat. Model pembelajaran sering pula diistilahkan dengan strategi pembelajaran atau strategi belajar mengajar. Bruce Joyce dan Marsha Weil (1986;25) menyebutkan bahwa strategi belajar mengajar adalah sebagai Models of Teaching.

Model pembelajaran konstruktivis dan model pembelajaran interaktif merupakan dua model pembelajaran yang dapat digunakan pada proses pembelajaran di tingkat pendidikan dasar. Menurut model konstruktivis, pengetahuan dibangun oleh siswa melalui kegiatan eksplorasi dan diskusi dengan temannya. Pengetahuan bukanlah seperangkat fakta, konsep, atau kaidah yang siap untuk diambil atau diangkat. Tetapi siswa harus mengkontruksi pengetahuan itu dan memberi makna melalui pengalaman nyata. Dalam model konstruktivis, keberhasilan belajar bergantung bukan hanya pada lingkungan atau kondisi belajar, tetapi juga pada pengetahuan awal siswa. Gagasan siswa yang diperoleh dari persepsinya terhadap alam sekitar yang dibawa dari 
rumah, sering kali berbeda dengan gagasan ilmiah. Dengan model konstruktivis, diupayakan pembelajaran yang memungkinkan siswa dengan sadar mengubah apa yang diyakininya yang ternyata mungkin tidak sesuai dengan konsep ilmiah. Menurut pandangan konstruktivis, proses pembelajaran didasarkan kepada anak membangun sendiri pengetahuannya dan banyak memperoleh pengetahuan di luar sekolah (Dahar, 1996;160). Fosnot $(1989 ; 19)$ mengemukakan empat prinsip dasar konstruktivisme. Pertama, pengetahuan terdiri atas konstruksi masa silam. Kita mengkontruksi pengalaman kita tentang dunia obyek dengan memandang melalui suatu kerangka logis yang mentransformasi, mengorganisasi dan menginterpretasikan pengalaman kita. Kedua, pengkontruksian pengetahuan terjadi melalui asimilasi dan akomodasi. Ketiga, mengacu kepada belajar sebagai suatu proses organik dalam penemuan, lebih daripada suatu proses mekanik dalam mengakumulasi. Konstruktivisme mengambil posisi bahwa siswa harus mendapat pengalaman berhipotesis dan memprediksi, memanipulasi obyek, mengajukan pertanyaan, mencari jawaban, berimajinasi, meneliti dan menemukan, dalam upaya mengembangkan konstruk-konstruk baru. Dalam perspektif ini jelas diperlukan proses pembelajaran yang berpusat pada siswa, dengan model instruksional yang aktif. Keempat, mengacu kepada mekanisme yang memungkinkan berlangsungnya perkembangan kognitif. Belajar bermakna terjadi melalui refleksi dan pemecahan konflik kognitif. Driver (1993;103) mengemukakan bahwa belajar menurut pandangan konstruktivis adalah proses aktif dan berkesinambungan yang dilakukan siswa dalam menggunakan informasi dari lingkungan untuk membangun interpretasi dan makna sendiri berdasarkan pengetahuan awal (prior knowledge) dan pengalaman. Bell (1993) merangkum komponen-komponen utama model konstruktivis dalam belajar seperti berikut : siswa secara aktif memilih dan mengamati beberapa informasi baru dalam lingkungannya, pengetahuan yang dimiliki siswa mempengaruhi stimulus yang akan diikuti, masukan yang dipilih dan diperhatikan tidak segera mempunyai makna baginya, siswa menyusun hubunganhubungan antara informasi baru dan ide-ide yang ada pada dirinya yang dianggap relevan, siswa mengkontruk makna dari hubungan-hubungan antara informasi baru dan pengetahuan yang telah dimilikinya, siswa mungkin menguji makna-makna yang disusunnya yang berlawanan dengan memori dan pengalaman yang dirasakan, siswa mungkin memasukkan konstruk-konstruk ke dalam salah satu memorinya dengan menghubungkan dengan ide-ide yang ada atau dengan cara membangun kembali ideidenya, dan siswa akan meletakkan beberapa status pada konstruksi baru dan menerima atau menolaknya.

Model pembelajaran interaktif merupakan model pembelajaran yang juga dikenal sebagai model pertanyaan siswa. Pada model pembelajaran ini, guru memberikan kesempatan kepada siswa untuk melakukan eksplorasi terhadap obyek yang akan dipelajari untuk membuat siswa mampu mengajukan pertanyaan-pertanyaan terhadap obyek yang diamatinya. Selanjutnya guru membimbing siswa untuk melakukan penyelidikan guna menjawab pertanyaanpertanyaan nya sendiri. Salah satu tujuan dari program pendidikan lingkungan di sekolah dasar adalah untuk membentuk sikap dan kepribadian yang positif dalam bentuk kegiatan, pembiasaan pola hidup yang menghargai lingkungan, membina kemampuan berinisiatif dan mengambil keputusan yang tepat dalam waktu singkat, yang salah satu di antaranya diwujudkan dengan menanamkan sikap ingin tahu pada siswa (Disdik Kota bandung;2008;2). Perasaan ingin tahu siswa itu di antaranya ditunjukkan oleh pengajuan pertanyaanpertanyaan yang dikemukakan oleh siswa. Akan tetapi seperti dikemukakan oleh Biddulph (1990;12) beberapa praktek pengajaran cenderung menghambat "pengajuan pertanyaan" siswa. Menurut Biddulph dan Osborne $(1990 ; 25)$ ada lima 
komponen utama pembelajaran interaktif dan empat peran fasilitatif bagi guru. Kelima komponen utama pembelajaran interaktif itu adalah persiapan, kegiatan penjelasan, investigasi anak, refleksi atau evaluasi.

Model pembelajaran interaktif adalah suatu pendekatan khusus yang meliputi kemampuan dan pertimbangan atas pertanyaan-pertanyaan siswa sebagai ciri sentral. Dengan kata lain dalam proses pembelajaran tersebut siswa akan bertanya dan kemudian melakukan penyelidikan tentang pertanyaan mereka sendiri (Bell, B.F;1993).

Salah satu contoh yang kontras antara pembelajaran interaktif dan konstruktif adalah penelitian Roscoe dan Chi (2007;321) yang membandingkan perbedaan cara belajar siswa, antara yang menjelaskan kembali pada temannya dan yang tidak setelah mempelajari suatu bagian tentang mata pada buku pelajaran. Siswa yang memiliki mitra diberitahu untuk menjelaskan isi teks tersebut dan membantu mitranya untuk benar-benar memahami teks mengenai mata tersebut. Siswa yang harus menjelaskan ini didorong untuk menjawab pertanyaan mitra mereka, yang secara tidak langsung juga memberi mereka kesempatan untuk menjadi interaktif. Siswa yang tidak memiliki mitra diberitahu untuk merekam apa yang dipelajarinya yang nantinya dapat digunakan oleh siswa lain untuk mencoba memahami materi. Pada kasus ini, siswa yang tidak memiliki mitra belajar, belajar melalui pembelajaran konstruktif, dalam hal ini dia dituntut untuk membuat dan menyusun materi serta untuk mempelajarinya lebih mendalam sehingga mereka dapat menjelaskan materinya dengan baik. Menurut Chi $(2009 ; 73)$ konstruktif, dan interaktif adalah istilah yang umum digunakan dalam pembelajaran ilmu pengetahuan alam. Keduanya menggambarkan kegiatan yang dapat dilakukan oleh peserta didik.

Salah satu kebutuhan yang sangat esensial bagi siswa adalah dapat memecahkan permasalahan yang dihadapi dalam kehidupan sehari-hari, terutama permasalahan yang berkaitan dengan lingkungan. Heylighen (2002) mengemukakan bahwa masalah adalah suatu situasi yang dialami oleh seseorang, sehingga apa yang dialaminya berbeda dengan apa yang secara ideal diinginkannya. Pendapat senada disampaikan oleh Domelen (2002) bahwa seseorang disebut mempunyai masalah apabila ada pemisah antara keadaannya dengan apa yang diinginkannya dan dia tidak tahu bagaimana menghilangkan pemisah tersebut. Suatu masalah dapat dipecahkan dengan berbagai metode sesuai dengan konteks masalah tersebut. Gagne (1985) memberi batasan bahwa pemecahan masalah adalah suatu proses di mana siswa menentukan kombinasi dan aturan-aturan yang telah dipelajari sebelumnya yang dapat dipakai untuk memecahkan masalah yang dihadapi. Sedangkan memecahkan masalah berarti menemukan jalan yang tepat untuk menjembatani kesenjangan yang ada. Van Domelen (2002) mencatat beberapa metode yang sering digunakan dalam memecahkan masalah yaitu The competent problem solver method, process control method, model-based "paradigm problem" method, basic mechanic method, dan electrostatic method.

Permasalahan lingkungan dapat meliputi aspek-aspek yang menjadi indikator merosotnya kualitas sumber daya kehidupan pada kegiatan masa lalu, saat ini dan prospek bagi kehidupan di masa yang akan datang. Aspek permasalahan lingkungan itu adalah pencemaran dan limbah, energi, degradasi lahan, keanekaragaman hayati, dan sumber daya air. Jadi kemampuan memecahkan masalah lingkungan adalah suatu kecakapan dalam membuat alternatif pemecahan masalah lingkungan yang berkaitan dengan pencemaran dan limbah, energi, degradasi lahan, keanekaragaman hayati, dan sumber daya air. Chiras (1985;176) mengemukakan bahwa permasalahan lingkungan dapat meliputi aspek-aspek yang menjadi 
indikator menurunnya kualitas sumber daya kehidupan pada kegiatan masa lalu, saat ini, dan prospek bagi kebutuhan di masa datang. Aspek permasalahan lingkungan itu adalah pencemaran dan limbah, energy, degradasi lahan, keanekaragaman hayati, dan sumber daya air.

Berdasarkan uraian di atas, maka yang dimaksud dengan kemampuan memecahkan masalah lingkungan adalah suatu kecakapan dalam membuat alternatif pemecahan masalah lingkungan yang berkaitan dengan pencemaran dan limbah, energy, degradasi lahan, keanekaragaman hayati, dan sumber daya air.

Ilmu Pengetahuan Alam (IPA) merupakan ilmu pengetahuan tentang alam semesta dengan segala isinya yang didapatkan melalui suatu proses untuk memperoleh kebenaran. IPA juga merupakan cara atau metode untuk mengamati alam yang bersifat analitis, lengkap, cermat, serta menghubungkan antara satu fenomena dengan fenomena yang lainnya sehingga keseluruhannya membentuk suatu perspektif yang baru tentang obyek yang diamatinya.

Dengan demikian, di samping penggunaan model pembelajaran yang tepat dan bervariasi, dalam pembelajaran PLH di SD diperlukan juga penguasaan konsep-konsep IPA yang relevan. Hal itu diperlukan untuk mengoptimalkan kemampuan siswa dalam memecahkan masalah-masalah lingkungan, sehingga siswa dapat mencapai tujuan pembelajaran PLH yaitu memecahkan permasalahan yang berkaitan dengan lingkungan hidup dalam kehidupan sehari-hari.

\section{Rumusan Masalah}

Berdasarkan latar belakang masalah di atas, dapat dirumuskan masalah : "Apakah terdapat interaksi model pembelajaran dan hasil belajar IPA terhadap kemampuan memecahkan masalah Lingkungan Hidup siswa sekolah dasar?"

\section{Tujuan Penelitian}

Adapun penelitian ini bertujuan untuk mengetahui : Interaksi antara model pembelajaran dan hasil belajar IPA terhadap kemampuan memecahkan masalah Lingkungan Hidup siswa SD.

\section{Metodologi Penelitian}

Penelitian ini dilaksanakan di SD Laboratorium UPI Kampus Cibiru Kecamatan Cileunyi Kabupaten Bandung Provinsi Jawa Barat. Metode yang digunakan dalam penelitian ini adalah metode eksperimen. Dalam penelitian ini, variabel bebas (variable eksperimen yang menjadi ruang lingkup penelitian adalah : (1) model pembelajaran konstruktivis, (2) model pembelajaran interaktif. Variabel terikat (variabel tercoba) adalah Kemampuan memecahkan masalah lingkungan hidup di sekolah dasar. Sedangkan sebagai variabel atribut adalah hasil belajar IPA, yang terdiri dari (1) hasil belajar IPA tinggi dan (2) hasil belajar IPA rendah.

$\begin{array}{lll}\text { Adapun rancangan } & \text { penelitian } \\ \text { yang digunakan adalah rancangan } \\ \text { factorial bertingkat dua atau rancangan } \\ \text { factorial } 2 \times 2 \text { sebagai berikut: }\end{array}$

Tabel 1. Rancangan Faktorial 2 x 2

\begin{tabular}{|c|c|c|c|}
\hline \multirow{2}{*}{\multicolumn{2}{|c|}{ Variabel $\mathrm{X}_{2}$}} & \multicolumn{2}{|c|}{ Model Pembelajaran ( A ) } \\
\hline & & Konsti & $\begin{array}{l}\text { Interaktif } \\
\qquad\left(\mathrm{A}_{2}\right)\end{array}$ \\
\hline \multirow{2}{*}{$\begin{array}{c}\text { Hasil } \\
\text { belajar } \\
\text { IPA (B) }\end{array}$} & Tinggi $\left(\mathrm{B}_{1}\right)$ & $\mathrm{A}_{1} \mathrm{~B}_{1}$ & $\mathrm{~A}_{2} \mathrm{~B}_{1}$ \\
\hline & $\begin{array}{c}\text { Rendah } \\
\left(\mathrm{B}_{2}\right)\end{array}$ & $\mathrm{A}_{1} \mathrm{~B}_{2}$ & $\mathrm{~A}_{2} \mathrm{~B}_{2}$ \\
\hline \multicolumn{2}{|c|}{ Interaksi } & \multicolumn{2}{|c|}{ A $\times$ B } \\
\hline
\end{tabular}

Populasi target dari penelitian ini adalah siswa sekolah dasar kelas 4 di Kecamatan Cileunyi Kabupaten Bandung. Sedangkan populasi terjangkau adalah Siswa kelas 4 SD Laboratorium UPI Kampus Cibiru. Sampel yang digunakan adalah siswa kelas 4 sekolah dasar Laboratorium UPI Kampus Cibiru sebanyak 80 orang siswa. 
Pengumpulan data dilakukan dengan menggunakan instrumen kemampuan memecahkan Lingkungan Hidup, dan instrumen pengukuran hasil belajar IPA. Sebelumnya, terlebih dahulu dilakukan uji coba instrumen, lalu hasil uji coba dianalisis melalui uji reliabilitas, uji validitas, dan uji daya pembeda.

Teknik analisis data yang digunakan adalah teknik analisis variansi (ANAVA) $2 \mathrm{x}$ 2. Sebelum menggunakan ANAVA $2 \times 2$ dilakukan pengujian persyaratan analisis yaitu uji normalitas dan uji homogenitas Hipotesis statistik yang diajukan dalam penelitian ini adalah:

$$
\begin{array}{lll}
\text { Ho } & : & \text { Int. } \\
\text { H1 } & : & \text { Int. }
\end{array}
$$

\section{HASIL PENELITIAN}

Rangkuman hasil perhitungan nilai hasil penelitian disajikan pada tabel berikut :

\begin{tabular}{|c|c|c|c|c|c|c|}
\hline & $\begin{array}{c}\text { NILAI } \\
\text { KONSTRUK } \\
\text { TIVIS } \\
\text { Kelompok } \\
\text { Tinggi }\end{array}$ & $\begin{array}{c}\text { NILAI } \\
\text { KONSTRUKTI } \\
\text { VIS } \\
\text { Kelompok } \\
\text { Rendah }\end{array}$ & $\begin{array}{c}\text { NILAI } \\
\text { INTERAKTIF } \\
\text { Kelompok } \\
\text { Tinggi }\end{array}$ & $\begin{array}{c}\text { NILAI } \\
\text { INTERAKTIF } \\
\text { Kelompok Rendah }\end{array}$ & $\begin{array}{c}\text { NILAI } \\
\text { KONSTRUKTIVI } \\
\text { S } \\
\text { Total }\end{array}$ & $\begin{array}{c}\text { NILAI } \\
\text { INTERAKTIF } \\
\text { Total }\end{array}$ \\
\hline$N$ & 20 & 20 & 20 & 20 & 40 & 40 \\
\hline $\bar{x}$ & 93,8000 & 81,0000 & 83,9000 & 78,8000 & 87,4000 & 81,3500 \\
\hline Median & 94,0000 & 79,0000 & 80,5000 & 79,0000 & 89,0000 & 80,0000 \\
\hline Mode & 94,00 & 75,00 & 75,00 & 71,00 & 94,00 & 75,00 \\
\hline $\operatorname{Max}$ & 100,00 & 96,00 & 95,00 & 96,00 & 100.00 & 96,00 \\
\hline Min & 80,00 & 71,00 & 75,00 & 67,00 & 71,00 & 67,00 \\
\hline$S$ & 5,65313 & 8,52242 & 7,81294 & 8,67907 & 9,64179 & 8,55015 \\
\hline$\sum x$ & 1876,00 & 1620,00 & 1678,00 & 1576.00 & 3496,00 & 3254,00 \\
\hline$\sum x^{2}$ & 176576 & 132600 & 141944 & 125620 & 309176 & 267564 \\
\hline
\end{tabular}

Tabel 1 Perhitungan nilai $n, \bar{x}, s, \sum \mathrm{x}, \sum \mathrm{x}^{2}$ hasil penelitian

Keterangan

$n \quad$ : banyak sampel setiap kelompok perlakuan

$\bar{x} \quad$ : rata-rata skor hasil kemampuan memecahkan masalah

$s \quad$ : simpangan baku

Sedangkan rincian hasil Anava dapat dilihat pada tabel beikut :

Tabel 2. Rangkuman Hasil Uji Anava Dua Jalan

\begin{tabular}{|l|r|r|r|r|r|}
\hline Source & $\begin{array}{c}\text { Type III Sum } \\
\text { of Squares }\end{array}$ & Df & \multicolumn{1}{c|}{$\begin{array}{c}\text { Mean } \\
\text { Square }\end{array}$} & \multicolumn{1}{c|}{ F } & Sig. \\
\hline Corrected & $2630.550^{\mathrm{a}}$ & 3 & 876.850 & 14.556 & .000 \\
Model & & & & & \\
Intercept & 569531.250 & 1 & 569531.250 & 9454.453 & .000 \\
$\mathrm{~A}$ & 732.050 & 1 & 732.050 & 12.152 & .001 \\
$\mathrm{~B}$ & 1602.050 & 1 & 1602.050 & 26.595 & .000 \\
$\mathrm{~A} * \mathrm{~B}$ & 296.450 & 1 & 296.450 & 4.921 & .030 \\
Error & 4578.200 & 76 & 60.239 & & \\
Total & 576740.000 & 80 & & & \\
Corrected & 7208.750 & 79 & & & \\
Total & & & & & \\
\hline
\end{tabular}

Berdasarkan hasil uji lanjut dengan menggunakan uji Tukey pada taraf signifikansi $\alpha=0,05$. Hasil kemampuan memecahkan masalah lingkungan hidup antara siswa kelompok rendah yang menggunakan model pembelajaran konstruktivis $\left(\mathrm{A}_{1} \mathrm{~B}_{2}\right)$ dengan siswa kelompok rendah yang menggunakan model pembelajaran interaktif $\left(\mathrm{A}_{2} \mathrm{~B}_{2}\right)$. Dari hasil uji lanjut diperoleh harga qhitung sebesar 1,268, sedangkan harga $\mathrm{q}_{\text {tabel }}$ pada taraf signifikansi $\alpha=0,05(\mathrm{dk}=4 / 80)$ sebesar $<3,74 \quad\left(3,74<q_{\text {tabel }}<3,68\right)$. Ini berarti $\mathrm{q}_{\text {hitung }}$ lebih kecil daripada $\mathrm{q}_{\text {tabel, }}$ atau ditulis $\quad\left(\mathrm{q}_{\text {hitung }}=1,268<\mathrm{q}_{\text {tabel }}=\right.$ $\left.3,74<\mathrm{q}_{\text {tabel }}<3,68\right)$ maka dengan demikian $\mathrm{H}_{0}$ diterima. Ditinjau dari data hasil penelitian pada kelompok rendah diperoleh harga rata-rata hasil kemampuan memecahkan masalah lingkungan hidup antara yang menggunakan model pembelajaran 
konstruktivis sebesar $\bar{x}=81,0000$ dan simpangan baku sebesar $s=8,52242$. Sedangkan harga rata-rata hasil yang menggunakan model pembelajaran interaktif sebesar $\bar{x}=78,8000$ dan simpangan baku sebesar $s=8,67907$.

Berdasarkan hasil perhitungan analisis varians (anava) dua jalan dengan taraf signifikansi $\alpha=0,05, \quad$ diperoleh hasil perhitungan harga $F_{\text {hitung }}=4,921$. Sedangkan $F_{\text {tabel }}$ dalam df1=1 dan df2=76 adalah 3,967. Dengan demikian harga $F_{\text {hitung }}$ lebih besar dibandingkan dengan harga $\mathrm{F}_{\text {tabel }}\left(\mathrm{F}_{\text {hitung }}=\right.$ $\left.4,921>\mathrm{F}_{\text {tabel }}=3,967\right)$, maka dengan $\mathrm{H}_{0}$ ditolak. Dapat disimpulkan bahwa terdapat pengaruh interaksi antara model pembelajaran dan hasil belajar IPA terhadap kemampuan memecahkan masalah lingkungan hidup di sekolah dasar.

\section{PEMBAHASAN HASIL PENELITIAN}

Hasil pengujian hipotesis

menunjukkan bahwa terdapat pengaruh interaksi antara model pembelajaran dan hasil belajar IPA terhadap kemampuan memecahkan masalah lingkungan hidup siswa SD. Dengan demikian dapat dijelaskan bahwa kemampuan memecahkan masalah yang dihasilkan dalam pembelajaran PLH selain dipengaruhi oleh model pembelajaran yang di gunakan juga dipengaruhi oleh hasil belajar IPA. Interaksi antara model pembelajaran dan hasil belajar IPA terhadap kemampuan memecahkan masalah lingkungan siswa SD dapat dilihat dari dasar pelaksanaan PLH yaitu menekankan pada pembentukan sikap dan perilaku peduli terhadap lingkungan hidup. Perilaku berhubungan langsung dengan niat untuk bertindak. Namun sebelum sampai kepada tindakan, terdapat beberapa faktor yang mempengaruhi yaitu kesiapan dalam bertindak, pengetahuan tentang strategi bertindak, pengetahuan tentang isu, dan faktor-faktor kepribadian. Seperti sikap dan tanggung jawab individu. Sikap dapat dibentuk sehingga terjadi perilaku atau tindakan yang diinginkan. Sikap sebagai ekspresi dari nilai atau pandangan hidup yang dimiliki seseorang. Sikap seorang siswa sangat dipengaruhi oleh kegiatan pembelajaran yang dia lakukan dan itu terfasilitasi melalui model pembelajaran, sedangkan nilai-nilai berkaitan erat dengan pengetahuan yang dia miliki, dalam hal ini adalah hasil belajar IPA.

\section{KESIMPULAN DAN SARAN}

\section{A. Kesimpulan}

Berdasarkan temuan-temuan dan deskripsi data hasil penelitian, pengujian persyaratan analisis dan pembahasan hasil penelitian, maka kesimpulannya adalah :

Terdapat interaksi antara model pembelajaran dan hasil belajar IPA, terhadap kemampuan memecahkan masalah lingkungan hidup pada siswa kelas IV SD yang mengikuti pembelajaran PLH.

\section{B. Saran}

1. Model pembelajaran konstruktivis dan model pembelajaran interaktif baik digunakan untuk pembelajaran pendidikan lingkungan hidup di sekolah dasar, agar siswa memiliki kemampuan memecahkan masalah lingkungan yang dihadapinya dalam kehidupan sehari-hari. Maka kepada guruguru pendidikan lingkungan hidup disarankan untuk menggunakan model-model pembelajaran ini.

2. Selain menggunakan model pembelajaran yang tepat, guru pendidikan lingkungan hidup di sekolah dasar alangkah baiknya juga mempertimbangkan hasil belajar IPA siswa dalam pembelajaran pendidikan lingkungan hidup. Karena hasil belajar IPA yang dimiliki siswa ternyata memiliki pengaruh terhadap kemampuan memecahkan masalah lingkungan sebagai hasil belajar pendidikan lingkungan hidup. 
3. Para guru pendidikan lingkungan hidup di sekolah dasar, hendaknya juga menggunakan penilaian proses dalam evaluasi pembelajaran pendidikan lingkungan hidup. Penggunaan penilaian proses ini akan membuat guru mengetahui kemampuan memecahkan masalah lingkungan yang dimiliki oleh siswa dalam tataran sikap, bukan hanya dalam tataran pengetahuan saja.

\section{DAFTAR PUSTAKA}

Ausabel, D.P. (1963). The Psychology of Meaningfull Verbal Learning. New York : Grune and Straton.

Bell, B.F. (1993). Children, Science, Constructivismand Learning in Science. Victoria : Deakin University.

Biddulph, F. (1990). Pupil Questioning as a Teaching/Learning in Primary Science Education.Same Papers, Centre for Science and Mathematics Education Research : Hamilton NZ: University of Waikato.

Bruce Joyce dan Marsha Weil. (1986). Models of Teaching. London : Pretic Hall International Inc.

Chi, Michelene T.H. (2009), ActiveConstructive-Interactive: A Conceptual Framework for Differentiating Learning Activities. Topics in Cognitive Science. Journal.

Chiras. D.D. (1985). Enviroment Science. A Framework For Decision Making. The Benjamin/Cumming Publishing Company, Menlo Park. USA.

Dahar, RW. (1996). Teori-Teori Belajar. Jakarta : Erlangga.
David P. Ausubel, (1963). The Psychology of Meaningfull Verbal Learning, New York : Grune \& Stratton, Inc.

Dinas Pendidikan Kota Bandung. (2008). Suplemen Kurikulum Muatan Lokal Pendidikan Lingkungan Hidup SD/MI. Bandung.

Driver, $\mathrm{R}$ dan Leach, J. A. (1993) Constructivist View of Learning : Children,s Conceptions and nature of Science. Journal NSTA; What Research Says to the Science Teacher The Science, Technology, Society Movement.

Driver, R. (1988) Changing Conceptions. Centre for Studies in Science and Mathematics Education. University of Leeds.

Fosnot, C. T. (1989). Enquiring Teachers Enquiring Leaners, a Constructivist Approach for Teaching. Teachers College Press : New York.

Heylighen, F. (2002) Problem Solving.(on line). Tersedia : http ://www. pesprnc1.uub.ac.be/problem - htm.

Kementrian Lingkungan Hidup. (2005). Sejarah Pendidikan Lingkungan Hidup di Indonesia. Tersedia : www.menlh.go .id, Jakarta.

Lee J. Cronbach. (1977). Educational Psychology. New York : Hardcourt Brace Jovanovich, Inc.

Lieberman, G.A. \& Hoody, L.L. (1998) Closing the Achievment Gap: Using The Environment nas an Integrating Context for Learning. San Diego:State Education and Environment Roudtable.

NAAE. (2001). Using Environmental-Based Education to Advanced Learning Skills and Character Development. 
Washington D.C : The National Environmental \& Traning Education.

Nomura K \& Hendarti, L. (2005). Environmental Education and NGOS in Indonesia, Jakarta: Yayasan Obor.

Nurhayati, L.A., Yufiarti dan Suhardi, E. (2012). Hubungan Antara Pengetahuan Lingkungan Hidup dan Kecerdasan Spiritual dengan Perilaku Hidup Bersih dan Sehat Siswa SMPN Kota Sukabumi. Jurnal Pendidikan Lingkungan Hidup.

Roscoe, R. D., \& Chi, M. T. H.. (2007). Tutor learning: The role of explaining and responding to questions. Instructional Science, Journal.

Rush, et al. (1999). Towards a Set of Principles for Effective Environmental Education Strategies and Programmes and Their Evakuation. Wellington : Agriculture New Zealand Ltd.

Sudrajat, Ahmad. (2008). Pengertian Pendekatan, Strategi, Metode, Teknik, dan Model Pembelajaran. http// akhmadsudrajat.wordpress.com/2008/0 9/12/pendekatan-strategi-metodeteknik-dan-model-pembelajaran.

Sulistyo Joko. (2010). Enam Hari Jago SPSS 17. Yogyakarta: Cakrawala.

Thomson, G dan Hoffman, J. (2002). Measuring the Succses of Environmental Education Programs. Canada-Ontario : canadian Parks and Wildernes Society and Sierra Club.

Van Domelen, D. (2002). Problem Solving Strategies: Mapping and Prescriptive Method. (on Line) Tersedia : http//www. Physics Ohio State Edu/dvandorn/edu/thesis. 